\title{
瀬戸内海地域養成ハマチの成長について
}

\author{
并上裕崔・日中㤵陽 \\ (1966 年 3 月 9 日受理)
}

\section{GROWTH OF HAMACHI, SERIOLA QUINQUERADIATA, CULTURED IN THE SETO INLAND SEA AREA}

\author{
Hiroo INOUE and Yoshiaki TANAKA*
}

For establishing the technology of pisciculture, it is necessary to be able to forecast the growth of the cultured fish. With this purpose in mind we have analyzed reliable field data concerning the average growth of the O-year-old yellow tail (Hamachi in Japanese) cultured in fish farms located on the Seto Inland Sea coast.

If the food supply is sufficient in quantity and adequate in quality when under the normal influence of all other possible factors, the average growth rate of the cultured fishes may be given as a function of water temperature (the most potent environmental factor) and average fish size (the most fundamental biotic factor) by the following empirical relationship.

$$
d\left(\frac{W}{W_{\infty}}\right) / d t=\lambda\left(1-\frac{W}{W_{\infty}}\right)\left\{\ln \left(1-\frac{W}{W_{\infty}}\right)^{-1}\right\}^{\gamma}
$$

where $W$ is the average body weight at time $t, W_{\infty}$ the theoretical maximum body weight $(\fallingdotseq 15.8 \mathrm{Kg}), d W / d t$ the growth rate, $\gamma$ a constant characteristic of the species and $\lambda$ depends upon the water temperature and perhaps upon the species.

In case of the 0 -year-old cultured yellow tail, the value of $\gamma$ was determined to be 0.167 (Fig. 1) and then the dependence of $\lambda$ upon the water temperature was accounted for as shown graphically in Fig. 2.

It may be thought that the amount of fish produced in any fish farm presents the "results" brought about by the combined action of natural and artificial factors on the growth of the fishes cultured there. Accordingly, the empirical relationship above shown will also serve as a standard of comparison with which to examine the actual growth of the cultured fish and to clarify the time when or the degree in which the adverse influence of some factors exercising on the growth shows itself.

Applied to the growth rate curve of fishes cultured in some fish farms different in shape, structure, rate of water exchange and degree of crowding of fishes, these procedures reached considerable success in diagnosing the environmental conditions existing during the course of culture and in obtaining correlations from which to predict the effect of some factors on the growth (Fig. 4).

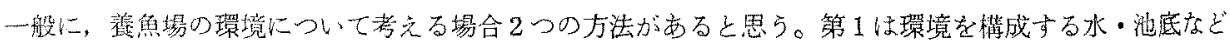

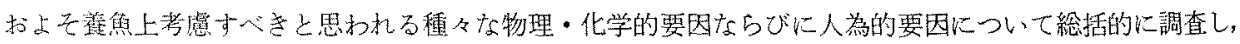

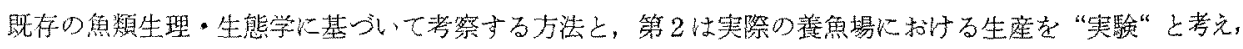
環境諸要因の作用の結果である成長データを解析して，これから逆に環境を推祭する方法である。最後にし の両者は有機的に就合されるべきことはもるるんである。第 1 の方法は正統であるが，錯綜した多くの要因

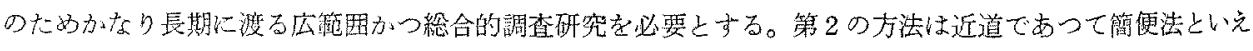

*香川大学震学部 (Fac. Agr., Kagawa Univ., Miki-cho, Kidangun, Kagawa, Japan). 
よ5。

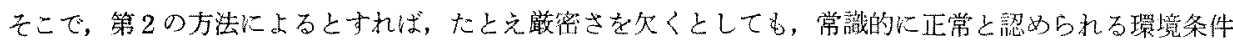
下での飼育魚について，成長速度 (日閒增重量)・日間㩑䬣量に対する基潐を設定する必要がする。この基準

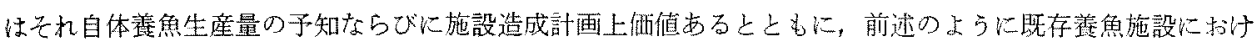
る成長・掑䭒データをこれと比較対照することによりその環筧の適否を診断する手掛りをあた兄る。

さて，魚類は変温動物であるから水温は代謝過程の速度を変える。水温の上昇によつて基礎代謝が盛儿に

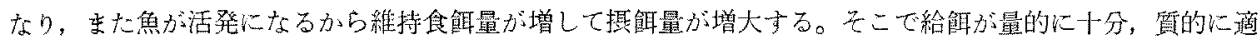
正でありさえすれば，魚はその存在する物理・化学的条件に対して可能な最大成長を澾することができる。 これら物理・化学的条件の中でもつとも基本的なのは水温と溶存酸素量 (D. O.) であるら。また他方, 成最 速度・日間摈钼量におよぼす生物的基礎要因としては魚体の大小・年令が考えられる。

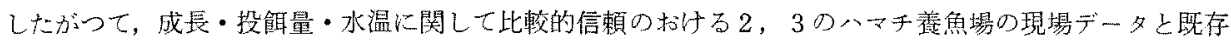

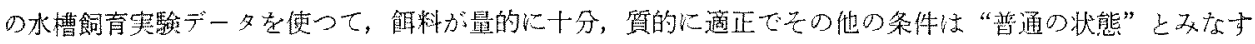

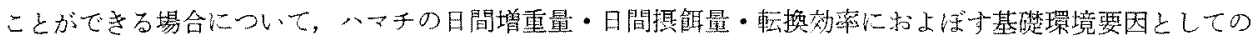

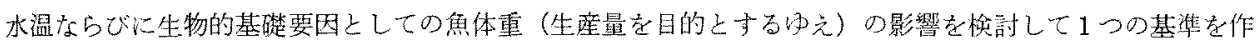
製してみることにした。まず本報では成長についてのべるとにする。

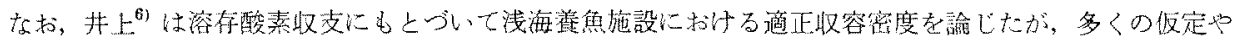
また簡単には教慮しえない諸条件の方に決して满足とは言るない。これを補足することにもなるら。

資料

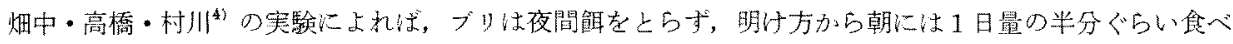

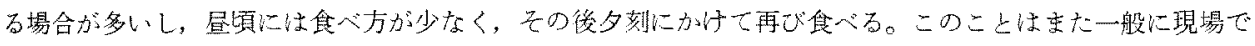

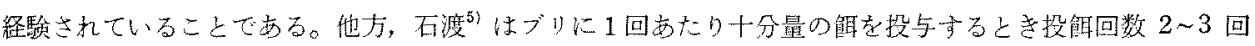

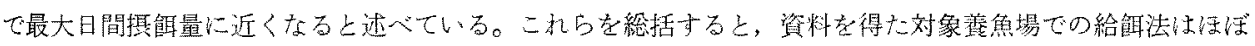
满足寸べきのであつて，最大日間抵䬦量に近い状態での給慨とみなしてよさそうである。

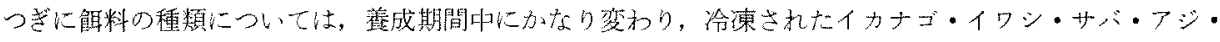

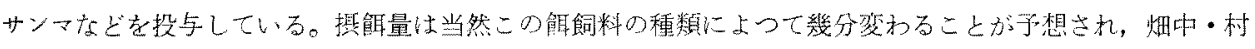
川光当指摘しているが，現場成長データはをれを十分区別して分析するだけ詳紐ではないのて，今後の水慒

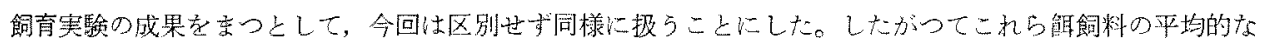
ものである。

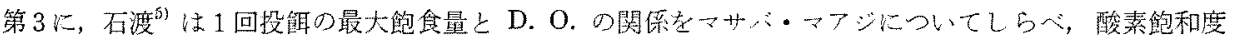

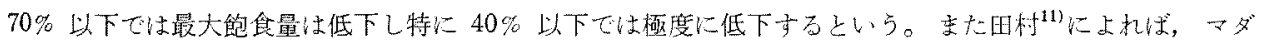


アイナメでは D. O.がある限度に涬するまて呼吸量は低下しないと述でている。一般に呼吸量が低下し始 わるときの D. O. と1回の最大飽食量が低下し始好るときD. O. との間に相関があると予想さ机る。

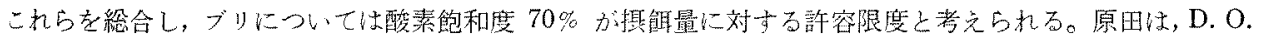

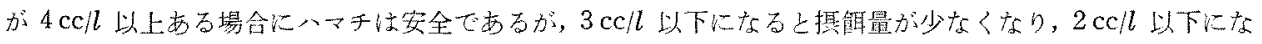
ると死亡する危除があるという。

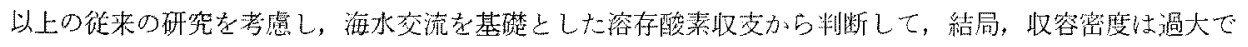
なく，給䬺が量的に十分・質的に適正で，普通の環境条件下でハマチが煡康に成省していたと思われる女木

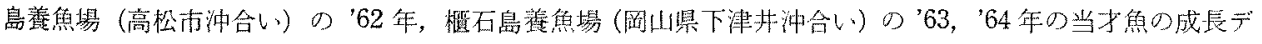

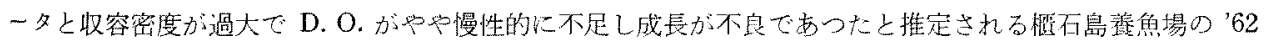
年のデータを使用することにした。両差魚場の説明については文献 7)，8）考参照されたい。

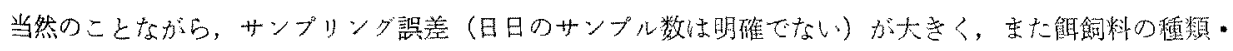


鮮度や生理上から生じる魚自体の日日の掑慨量の垐動のため，毎日測定した粗资料としての平均魚体重は信

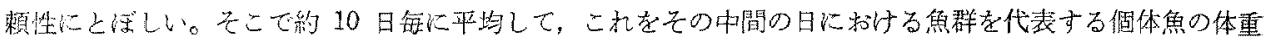
とみなすよらに再整理した。以上の前処理で得たものを資料として日間增重量（成辰速度）を通常の方法で 求的大。

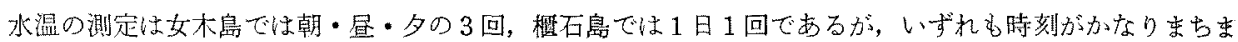
ちで欠測もある。こで焦体重の場合上同様に約 10 日每の乎均值で代表させた。

\section{解析の方法}

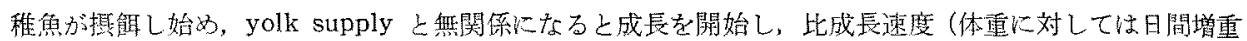
率）は生理的サイタル飞よるもの含めて一般に变動するが，平均的には一定ないしは濑次減少しながら成

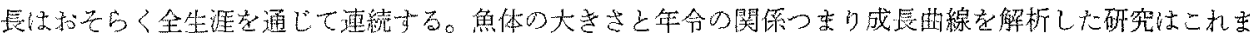
で非常に多いが，Medawar"璂本式を次のように表現した。

$$
d(\ln W) / d t=K \Phi(t)
$$

$W$ は魚体の大きさ（体重でも体長でもよい）， $t$ は時間（多くの場合は年単位）。比較的長い期間の平均优を

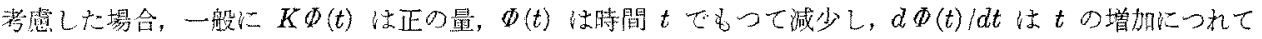
增し0に近づく。

ここで対象とする瀬不内海地域ては当才ブリ（ハマチ）の短期養成にこれまでの魚体大きさ対年命の関倸 式（この場合年平㚬の環境条件は注とえぞ変わらないと考えている）をえのまま適用したのでは十分でない。 基濋環境条件上しての水温の影響を考慮に入れて少し暹つた解析を就みることにする。

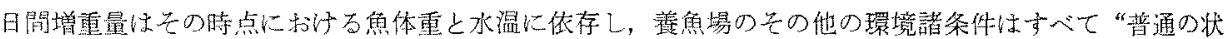

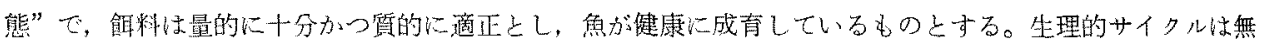
視子る。

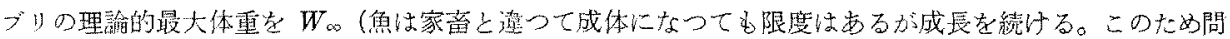

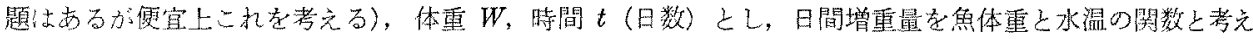
て次のように表わされるものとしよう。

$$
d\left(\frac{W}{W_{\infty}}\right) / d t=\lambda\left(1-\frac{W}{W_{\infty}}\right)\left\{\ln \left(1-\frac{W}{W_{\infty}}\right)^{-1}\right\}^{r}
$$

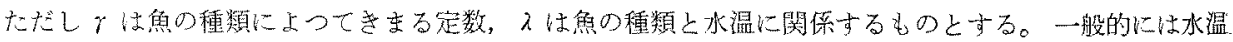
は時間の関数でる。

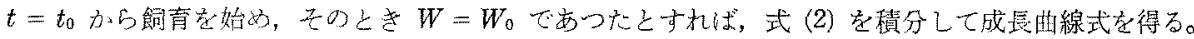

$$
\begin{aligned}
W / W_{\infty} & =1-\exp \left\{-\left[\left\{\ln \left(1-\frac{W_{0}}{W_{\infty}}\right)^{-1}\right\}^{\frac{1}{n}}+\frac{1}{n} \int_{t_{0}}^{t} \lambda d t\right]^{n}\right\} \\
& =1-\exp \left\{-\left[\left\{\ln \left(1-\frac{W_{0}}{W_{\infty}}\right)^{-1}\right\}^{\frac{1}{n}}+\frac{t-t_{0}}{n} \lambda\right]^{n}\right\} \cdots
\end{aligned}
$$

ただし $n=\frac{1}{1-\gamma}, \bar{\lambda}=\frac{1}{t-t_{0}} \int_{t_{0}}^{t} \lambda d t$ である。

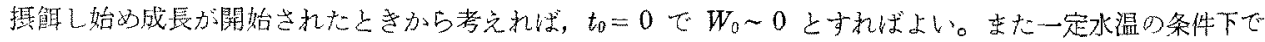
は $\lambda=\bar{\lambda}=$ const. と补げよいことなる。したがつて成長が開始されたときから考充，しかも水温が定 であるとすれば，簢単に

$$
W / W_{\infty}=1-\exp \left\{-\left(\frac{\lambda}{n} t\right)^{n}\right\}
$$

この式は粉体工学における Rosin-Rammler の粒径分布式と形式上同じである。実のところ式 (2)はこの Rosin-Rammler の分布式上り推定して誘導したのである。な扰 (3) 式を $t$ とついて微分すれば容易に 
Medawar の一般式 $K \Phi(t)$ の関数形录すことができる。

\section{結果亡考察}

三谷・恢藤 ${ }^{10)}$ はブリの尾叉体長と年命の閔係研究し定差图にもとついて理諭最大尾叉体長を与えている ので,これから対応する理譣最大体重 $W_{\infty}$ を推定した。 $W_{\infty}=15.8 \times 10^{3} \mathrm{~g}$ とる。

日閒增重量が式 を $\log \left(1-\frac{W}{W_{\infty}}\right)^{-1}$ に対して雨対数紙上にプロット寸れ倡平行直線群がえられるはずである。林島'62年,

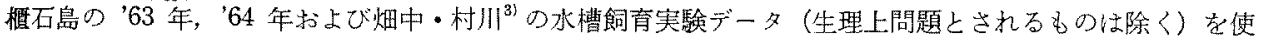
つて計算した結果を Fig. 1 にしめす。このよらに比較的狭い水温籍用に群別すれば，ほ涪平行な植線群と 欢して差支なく、したがつてをの公配けは 水温と恃無閣保で魚の種制に上つてきまる定数 と考えられるし，また入は水温に依存するこ とも明らかである。ここではケ $=0.167$ とな to

次に入が水温 $\theta$ によつてどの上らに变わる かを知るため，この $\gamma$ 值を使つて式 (2) 上り それ杂れ入求め，乙の時の水温に対してプロ ットしたのが Fig. 2 である。一般に経験的に は次のことが知られている。才なわら，ハマチ

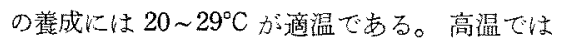

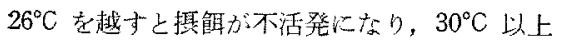
になると注意を要し， $31^{\circ} \mathrm{C}$ 以上では游泳が異 常となり危険である。他力, 低温では $14^{\circ} \mathrm{C} ま$

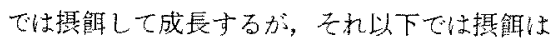
するが成長しなくなりかえつて体重を城じる。

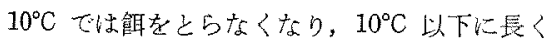

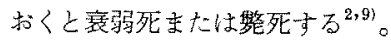

Fig. 2 に和忛る各点は尒想される上5にか なりバラッキがあるけれども， fitted curveを 描けばこの経験的記述に上く合致するこしがわ かる。 $\lambda$ の值つ主体重於同じ場合の日間增 重量は水温 $14^{\circ} \mathrm{C}$ 前後て $0,15^{\circ} \mathrm{C}$ 名 $19^{\circ} \mathrm{C}$ ま

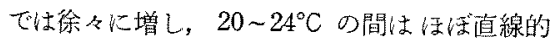
に急增する。水温少: $24^{\circ} \mathrm{C}$ 老越才之入增し 方が次第に小さくなつて $26 \sim 27^{\circ} \mathrm{C}$ の間て最大 となるようである。2 $8^{\circ} \mathrm{C}$ 以上ては急激に減少 寸る有様がらかがるが、データが分でない ため断定できない。

干満潮差型のハマ虚魚場で夏季昼間下げ潮 畤にかなり水温が上昇し $29 \sim 30^{\circ} \mathrm{C}$ に墶るるこ とがある。たとえ D. O.が普通であつても， この昇温は魚の成長悪影響していることが言 えそらである。

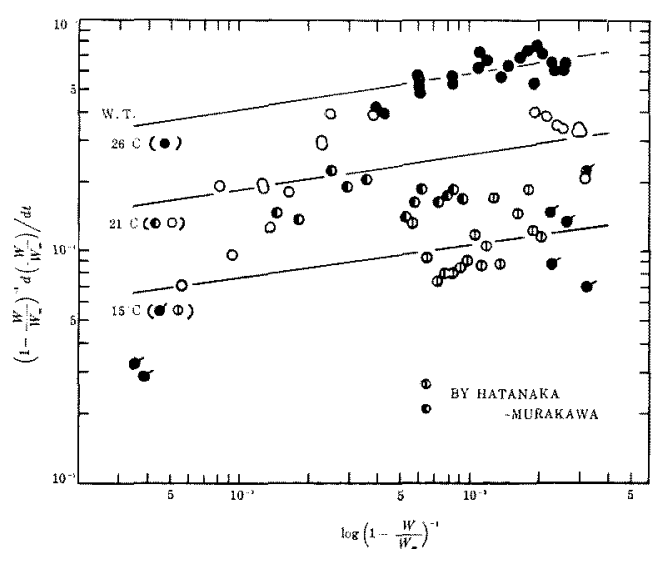

Fig. 1. Determination of $\gamma$ in Eq. 2 (Temperature range: $26 \pm 1.5$, $\left.21 \pm 1.5 .15 \pm 2.0^{\circ} \mathrm{C}\right)$.

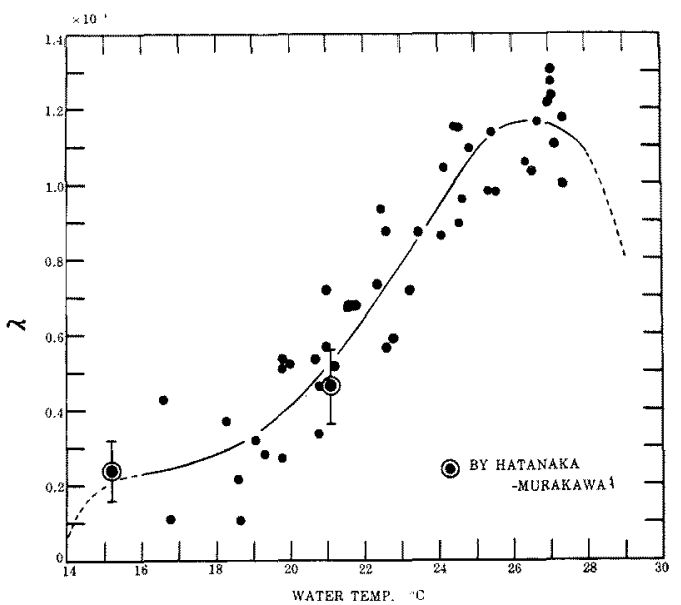

gig. 2. Dependence of $\lambda$ in Eq. 2 upon water temperature. 
ここで得られた成長と水温の間の関倸は，すでに Audigé が2，3の魚について定性的に傾向として見 出したものと一致する。しかし Salmo trutta についての実験ではこの傾向が少し異なつてくるらしい。 つまり成與速度に対する適温は 2 点にあらわれ，その前後怙上び中間の温度領域では成長速度が低いとい $5^{11}$ 。

結局賴戸内海盖成ハマチについて次の上5に要約される。養魚場の環境条件がすべて普通の状態で，給触 が質・量ともに十分，魚が健康に成育している埸合 について，ある時点に抢ける水温を知孔ば Fig. 2 よりスが定をり，その時の魚体重Wを知つて式 （2）から対応基準日間增重量を見積ることが可能と なつた。Fig. 3 はこれを放り易く図示したもの である。また他方，秘成初期の魚体重から出発し て, 責成期間中成長を阻害する上らな環境の変化が 起こらない場合，氷温変化比応じた基準成長は式 (3) から容易に推算される。したがって逆にある 養魚場での実際の日間增重量と前記の計算にしたが 万対応基準日間增重量とを比較検討寸れば，璝境要 因の影響の時期とその度合，飼育法の欠宿などを知 ることができ，一つの指標として役立つことにな る。

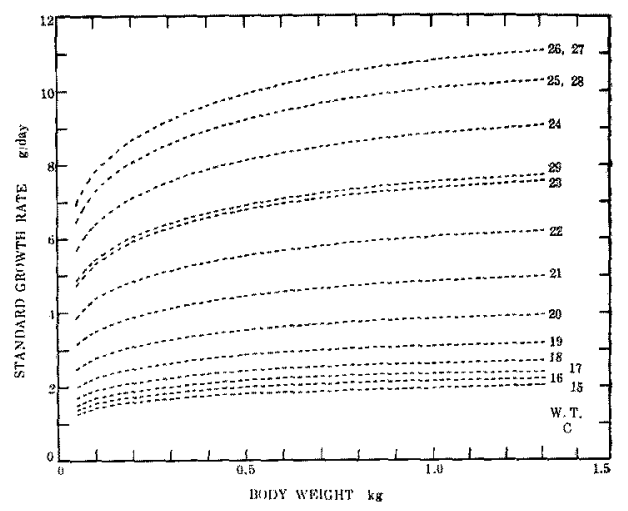

Fig. 3. Standard growth rate calculated from Eq. 2.

庶

用

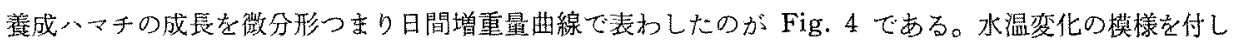
た。军際の盖成過程中のある日の水温と魚体重から得られる対応基準日間增重量は，その日以前に成長を阻
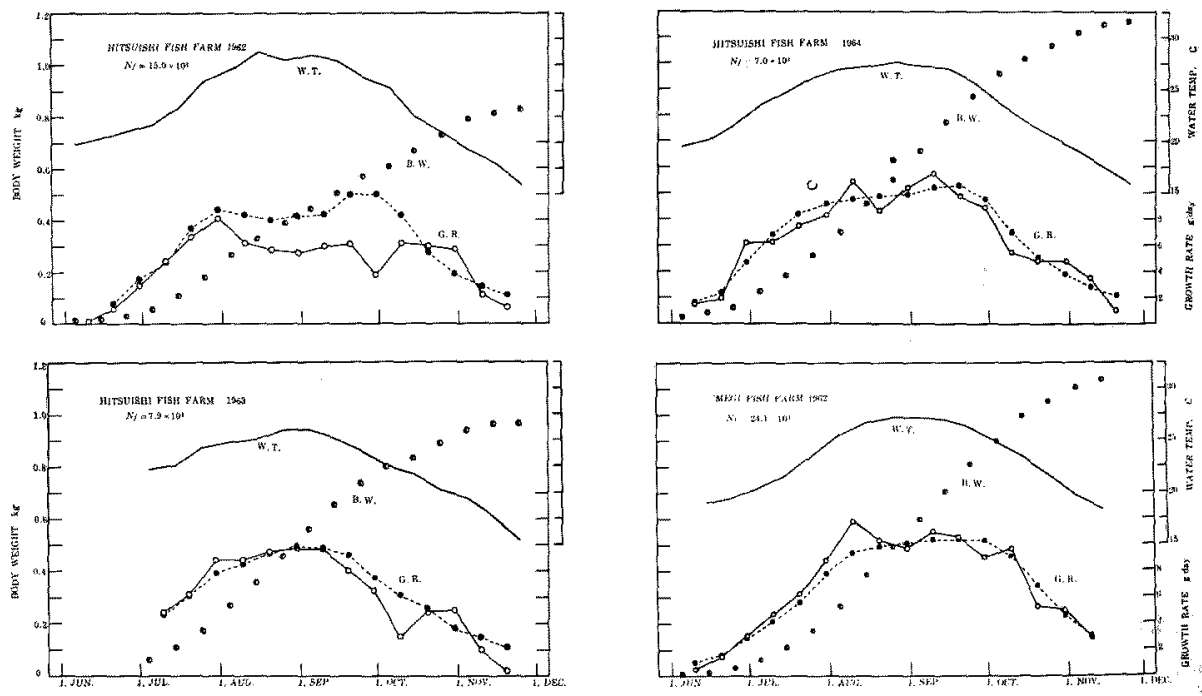

Fig. 4. Comparisons of actual growth rate curves in $\mathrm{Hi}$ tsuishi and Megi fish farms (O) with standard growth rate curves (O): $N_{f}$ presents the number of fishes produced. 
さ環境要因の作用がなければ，式 (3)により定められた基準成長曲線の微分形表示である基準日間增重量曲 線上に位置することになる。しかしある日以前に成長を阻さ環璄变化を経験しても，それがさほど大きくな けれ杖，その日の水温・魚体重から求まる対応基蕉日間増重量は初期魚体重に基ついて推定される基準日間 增重䁷にほぼ等しいことは Fig. 3 から理解されよう。そこでそれぞれの日の対応基潮日間增重量を示す点 を結べば近似的に基準日間增重量曲線とみなしてよいことになる。Fig. 4 に対広基準日間增重量をプロッ トし，実際の荃成成績と比較対䁷した。

女木島の'62 年は全善成期間に渡りよく一致する。換言すれば基礎環境要因の水温が成長を支配していて， その他の要因はほぼ正常上思われる。つまり収容尾数が過密でなくまた良好な站魚場上いえる。

㰓石島 '63, '64 年もよく一致するが，ただ9月下旬〜 10 月上旬にかけて, '63 年はかなり顕藷に, '64は ごくわずかに日間增重量の部分的低下の現象認める。これは执らく成層消隇による上下層の混合ないし

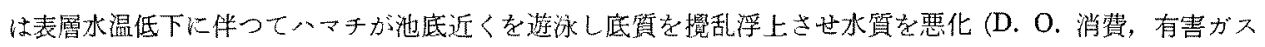
の発生など)するのが主因上推定して妾ず誤りはないだるら。これによる减重䁷つまり欠損面樍は’63 年的

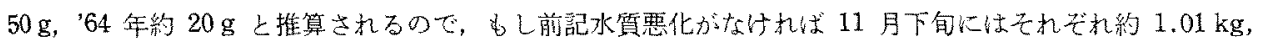
$1.18 \mathrm{~kg}$ にまで成烱していたである5。このよらに考えても’63 年にはたかだか $1.0 \mathrm{~kg}$ 程度にしか澾し なかつたのは水温が 6 月下旬 10月上旬の間全般に 1 2 ${ }^{\circ} \mathrm{C}$ 低からたことに上る。とこるが相石島 62 年 の成績老及る上同様に 9 月下旬 10月上旬の成育阻害現象が恋められるが，それ以上に7月下旬頃より收 容尾数の過多に上る D. O. の慢性的不足のあら放指摘し得る。かりにD. O. の慢性的不足だけで，9 月〜10月の水質昰化がなければ 30 40 g の增重となる。またこれらいずれるが起こらなければ約 $220 \mathrm{~g}$ の增重となり，11 月下旬には添 $1.05 \mathrm{~kg}$ の魚体重に成育していたであ万ら。この年は6月中旬〜 7 月中 旬にかけて水温やや低く，8月高過ぎたよらである。

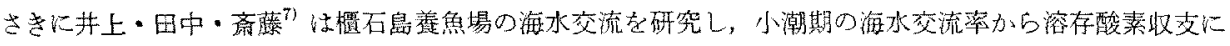
基ついて適正取容尾数を論じたが，本報の成長解析はこれを十分補足するものである。


の速い流れがたえずある。東流時にはこのみ朽筋の東端，西流時には西端掼で投慨するようにしているため， 残䬣・非泄物などは域外に流去すること多く，局所的な集中堆皘がない。その上全面的に水变わりが上いた

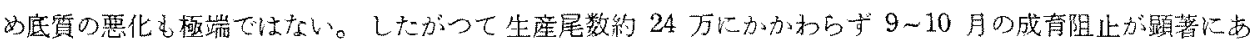
らわれないのであるう。しかし樻石鼠では局部的深所があつてこの位置が投慨場になつている。その他は全


することが洘えられる。64 年は’63 年に引続いて収容尾数が少なかつたのて，底筫惠化の影響が小さかつ たのである5。

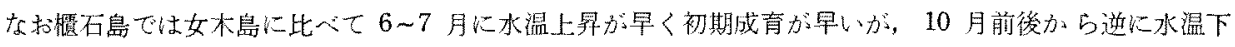

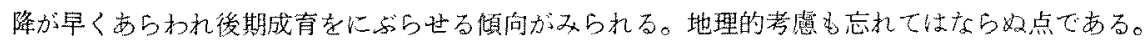

\section{あとがき}

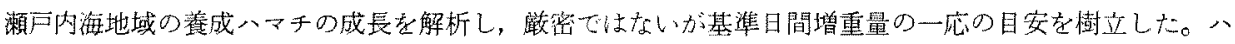
マチ養成施設の造成計画，環境診断，飼育法診断，生滻量予知などに，そしてまた幾分は生態学上役文つも のと愚われる。

たとえば，(1) 収容尾数の過多による慢性的なD．．の不足，あるいはプランクトンの極度の增減に上 る一時的な D. O.の不均衡があつたのではないか，(2) 水温が低すぎたり高すぎたりしたことの影繁はど の程度か，(3) 底質がかなり老化していて，9月・10月の成層消隇期における上下㞗の混合，あるいは同じ

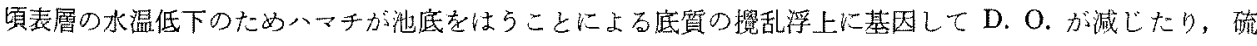

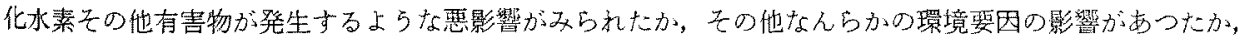

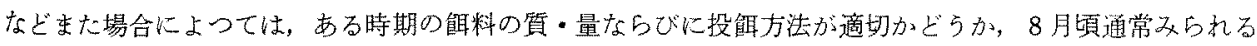




\section{4}

濁りはどの程度影響したか，などの多くの問題をその時点に执いて考えさせ，単代定性的にとどあらずある 程度定量的に原园・対策家さぐり出す手助けとなるである5。さらに多くの資料老得て改良する余地はある

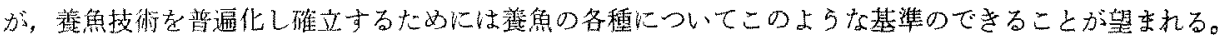

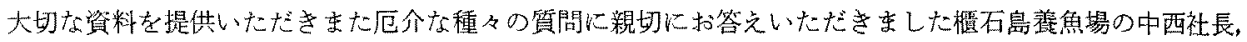
中村・大森雨氏，女本島盖魚場の山林社長の备位に心から礼申し上げ市。また東京大学杉二郎教授には 御指導を賜り，本学岡市友利助教授には文献その他種々御世話になりました。付記して謝意を表します。

\section{文献}

1) M. E. Brown: in "The physiology of fishes" (M. E. Brown, ed.), Vol. I, 361 398, Academic Press, New York. (1957).

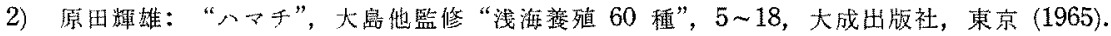

3) M. Hatanaka - G. Murakawa: Tohoku J. Agr. Res., 9, $69 \sim 79$ (1958).

4) 烟中正声・高橋䠌雄・村川五郎：本誌, 24 (4), 251 255 (1958).

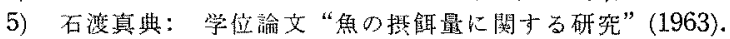

6) 井上裕雄：水産增殖臨眭号 4, 61 77 (1965).

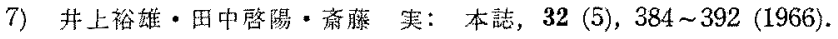

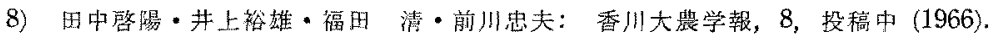

9) 㰌高二郎: 水應增殖, 7 (1), 7 30 (1959).

10) 三谷文夫・佐藤啠战：本誌，24 (10), 803 808 (1959).

11) 田村 正：水学雑，54，40 47(1949). 